\title{
EFFECTS OF AMOUNT AND TYPE OF DIETARY FAT ON SERUM LIPIDS, LIPOPROTEINS AND APOLIPOPROTEINS IN MAN
}

\author{
A Controlled 8-Week Trial
}

JANTINE H. BRUSSAARD ${ }^{1}$, GEESJE DALLINGA-THIE ${ }^{2}$, PIETER H.E. GROOT ${ }^{2}$ and MARTIJN B. KATAN ${ }^{1}$

${ }^{1}$ Department of Human Nutrition, Agricultural University, Wageningen, and ${ }^{2}$ Department of Biochemistry 1, Erasmus University, Rotterdam (The Netherlands)

(Received 29 October, 1979)

(Revised, received 13 March, 1980)

(Accepted 18 March, 1980)

\section{Summary}

We have studied whether a low-fat diet is as effective in lowering some risk factors for atherosclerosis as a diet rich in polyunsaturated fat (PUFA). During a 2.5 week control period, 60 volunteers were given a moderate-fat diet (MOD) providing $30 \%$ of the daily energy intake (energy \%) in the form of fat, onethird of which was PUFA. For the next 5 weeks subjects were divided into 4 groups and received diets providing varying amounts of total fat and of PUFA: for group LO, 20 energy \% fat and 3 energy \% PUFA; group MOD, 30 energy \% fat and 11 energy \% PUFA; group HIPUF, 40 energy \% fat and 19 energy \% PUFA; and group HISAT, 40 energy $\%$ fat and 3 energy \% PUFA. The diets contained the same amounts of cholesterol, phytosterols, oligosaccharides and other nutrients, known to affect serum lipid levels. All food was prepared daily and weighed out for each individual appropriate to his energy needs. Nutrient intakes were checked by 7-day records and by chemical analysis of double portions.

On diet LO, total serum cholesterol concentration increased by 0.25 mmol/1 while HDL cholesterol concentration did not change significantly. The

This work was supported by The Netherlands Heart Foundation, Grant 77.082.

Correspondence to: J. Brussaard, Agricultural University, Department of Human Nutrition, De Dreijen $11,6703 \mathrm{BC}$ Wageningen, The Netherlands.

Abbreviations: CVD, cardiovascular disease; HDL, high density lipoprotein; LDL, low density lipoprotein; VLDL, very low density lipoprotein; PUFA, polyunsaturated fatty acids; energy \%, percent of daily energy intake. 
HDL cholesterol/apoprotein- $\mathrm{A}_{1}$ ratio fell, and VLDL and LDL triglyceride concentrations were elevated.

On the HIPUF diet, total serum cholesterol concentration was not significantly lower, but HDL cholesterol concentration increased by $0.10 \mathrm{mmol} / \mathrm{l}$. On the HISAT diet, total serum cholesterol concentration went up by 0.38 $\mathrm{mmol} / \mathrm{l} ; 0.12 \mathrm{mmol} / \mathrm{l}$ of this was due to HDL.

LDL cholesterol/serum apoprotein-B ratios were unaffected by any of the diets.

It was concluded that after 5 weeks, the influence of a low-fat, high-carbohydrate diet on the concentrations of serum lipoproteins was less favourable than that of moderate- or high-fat diets rich in polyunsaturated fatty acids.

Key words: Apolipoproteins - Carbohydrates - Dietary fat - HDL cholesterol - Linoleic acid-Serum cholesterol

\section{Introduction}

During the last two decades, prospective epidemiological studies have shown that the risk of cardiovascular disease (CVD) increases with increasing plasma concentrations of total or LDL cholesterol [1] and decreases with increasing HDL cholesterol [2-4]. Plasma HDL cholesterol concentration is reduced in several conditions associated with an increased risk of future CVD namely hypercholesterolemia, hypertriglyceridemia, obesity and diabetes mellitus $[5,6]$. Subjects with existing clinical atherosclerotic disease also have lower levels of HDL than healthy subjects within the same community $[5,7,8]$.

In order to elucidate the metabolic origin of differences in lipoprotein lipid levels interest has focussed recently on the measurement of the apolipoproteins of LDL and HDL. Apo-B, the main apoprotein of plasma LDL, is substantially increased in the plasma of subjects with hypercholesterolemia, while endogenous hypertriglyceridemia is associated with a mild increase in plasma levels of apo-B $[9,10]$. In the latter instance the increase in serum apo-B is mainly located in the VLDL fraction.

Apo- $A_{1}$, the main apoprotein of plasma HDL, is found to be reduced in survivors of myocardial infarction as compared with controls [11] and the HDL cholesterol/apo- $A_{1}$ ratio was also lower in this condition [8]. At the other end of the risk scale, HDL cholesterol/apo- $A_{1}$ ratios were higher in a low-risk group of vegetarians than in a control group [12].

Many short-term experiments have shown that on diets in which saturated fat is replaced by polyunsaturated fat the serum cholesterol and triglyceride levels are lowered; in long-term intervention trials a reduction in the incidence of cardiovascular disease was also noted $[13,14]$. As a result of such studies, diets high in polyunsaturated fat have been advocated for the prevention of CVD, and consumption of vegetable oils in the U.S. has indeed risen considerably during the last decade [15]. There are fewer controlled studies in man on the effect of replacing saturated by polyunsaturated fat on the concentration and composition of separate lipoproteins, while studies on the effect of natural low-fat diets in healthy subjects are quite rare. 
We have investigated the effects of a low-fat diet on serum lipids, lipoprotein composition, blood pressure and faecal steroids as compared with a moderatefat, high-polyunsaturated diet, containing the same amounts of cholesterol and other nutrients that may affect serum lipid levels. In the present paper results of lipoprotein, apo- $\mathrm{A}_{1}$ and apo-B analyses will be presented.

\section{Subjects and Methods}

\section{Selection of subjects}

Thirty-seven male and 23 female university students, aged 18-28 years participated in this study. The subjects were all volunteers who satisfied the following criteria:

apparently healthy, as judged by a detailed questionnaire;

serum cholesterol concentration below $5.7 \mathrm{mmol} / \mathrm{l}$;

serum triglyceride concentration below $1.7 \mathrm{mmol} / 1$;

diastolic blood pressure below $90 \mathrm{~mm} \mathrm{Hg}$;

percentage of body fat below $23 \%$ in males and $30 \%$ in females as determined by skin fold measurements.

Only two of the females used hormonal anticonception.

Experimental design, diets and control of food intake

During the first 2.5 weeks of the study all subjects consumed a control diet (MOD) which was moderate in fat and relatively high in PUFA (30 energy \% total fat, 10 energy \% PUFA) in agreement with the recommendations of The Netherlands Nutrition Council. After this period, 4 subgroups were formed which received diets as presented in Fig. 1. The groups were matched for initial serum cholesterol, energy intake and sex. Mean body weights per group were $67.2,66.6,64.9$ and $66.0 \mathrm{~kg}$ for groups LO, MOD, HIPUF and HISAT respectively. Throughout the 8 -week period all foodstuffs were weighed out for each person in quantities appropriate to his energy needs, except for $100 \mathrm{kcal} /$ day, which the subjects were free to spend at will. Average energy intake during the control period was $11.1 \pm 3.6 \mathrm{MJ}( \pm 1 \mathrm{SD})(2643 \pm 854 \mathrm{kcal})$. Actual nutrient intakes were checked by 7-day individual food records using Dutch food composition tables [16], and by double-portion analysis [17] for one imaginary person of average energy intake on each diet. Mean daily intakes on nutrients are given in Table 1. Analysis of double portions revealed a slightly

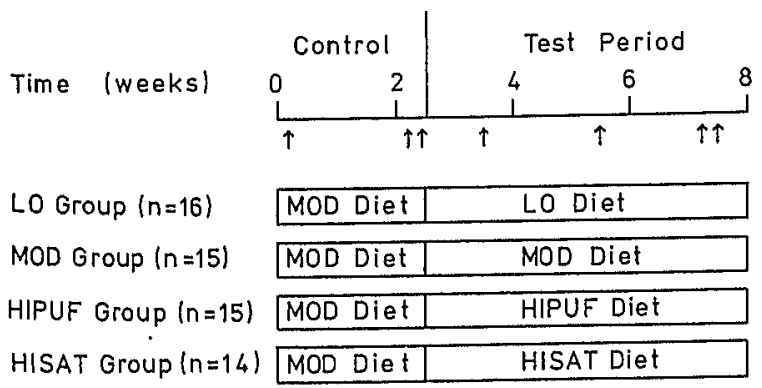

Fig. 1. Experimental design. Blood sampling is indicated by arrows. 
MEAN DAILY INTAKE OF NUTRIENTS ACCORDING TO INDIVIDUAL FOOD RECORDS a

\begin{tabular}{|c|c|c|c|c|c|c|}
\hline & \multirow{2}{*}{$\begin{array}{l}\text { Habitual } \\
\text { intake } \\
\text { before } \\
\text { experiment } b\end{array}$} & \multirow{2}{*}{$\begin{array}{l}\text { Control c } \\
\text { period }\end{array}$} & \multicolumn{4}{|c|}{ Experimental period $d$} \\
\hline & & & Lo & MOD & HIPUF & HISAT \\
\hline Energy (MJ) & 11.4 & 11.1 & 10.6 & 10.5 & 10.7 & 10.3 \\
\hline (kcal) & 2734 & 2646 & 2517 & 2517 & 2552 & 2455 \\
\hline Protein (energy \%) & 13 & 14 & 13 & 14 & 14 & 13 \\
\hline vegetable & 6 & 7 & 6 & 7 & 7 & 6 \\
\hline animal & 7 & 7 & 7 & 7 & 7 & 6 \\
\hline Total fat (energy \%) & 32 & 30 & 22 & 30 & 40 & 39 \\
\hline saturated & 15 & 10 & 8 & 10 & 11 & 18 \\
\hline monounsaturated & 11 & 8 & 10 & 8 & 8 & 16 \\
\hline polysaturated & 5 & 11 & 3 & 11 & 19 & 3 \\
\hline Carbohydrates (energy \%) & 50 & 54 & 64 & 54 & 44 & 46 \\
\hline sugars & 24 & 22 & 21 & 2.1 & 21 & 23 \\
\hline polysaccharides & 27 & 32 & 43 & 33 & 23 & 23 \\
\hline Alcohol (energy \%) & 4 & 1 & 0 & 1 & 1 & 2 \\
\hline Vitamin C (mg) & 109 & 110 & 100 & 103 & 100 & 107 \\
\hline Cholesterol (mg/1000 kcal) & 106 & 114 & 102 & 113 & 104 & 86 \\
\hline Phytosterols (mg/1000 kcal) e & & 160 & 98 & 158 & 107 & 214 \\
\hline Dietary fiber $(\mathrm{g} / 1000 \mathrm{kcal})$ & 15.0 & 10.0 & 9.7 & 9.4 & 9.7 & 10.5 \\
\hline
\end{tabular}

a The food records were elaborated using the Netherlands food composition tables.

b 3-day records.

c 2-day records.

d 5-day records.

e Measured by analysis of duplicate portions providing $2700 \mathrm{kcal} / \mathrm{day}$.

higher proportion of fat in the total daily energy intake in all groups, but the differences between groups in fat intake, fatty acid composition and other nutrients agreed well with the food records. Body weight was recorded weekly. Energy intake was adjusted when necessary in order to avoid changes in body weight of more than $2 \mathrm{~kg}$.

The mean change per group in body weight over the 5 weeks of the test period ranged from $-0.4 \pm 1.1$ to $-0.8 \pm 1.4 \mathrm{~kg}$.

Stools were collected for 7 days at the end of the control and the test periods. There were no differences between the groups in intestinal transit time [18], faecal output and moisture content or frequency of stools in either period.

\section{Blood sampling and analysis}

Blood samples were taken after an overnight fast before and during the experimental period as indicated in Fig. 1 . No alcohol was allowed during $24 \mathrm{~h}$ prior to blood sampling. Serum was obtained by low-speed centrifugation. Serum cholesterol was measured according to Huang et al. [19] using serum calibrators calibrated as described by Abell et al. [20]. Reproducibility for blind control sera provided by the Center for Disease Control, Atlanta, GA, U.S.A., was $\pm 0.9 \%$ and accuracy was within $1.4 \%$ of the "true" (target) values. HDL cholesterol was determined after manganese-heparin precipitation of apo-B containing lipoproteins [21] as previously described [22]. At the end of the control and the test periods, sera were collected for apolipoprotein- $A_{1}$ and 


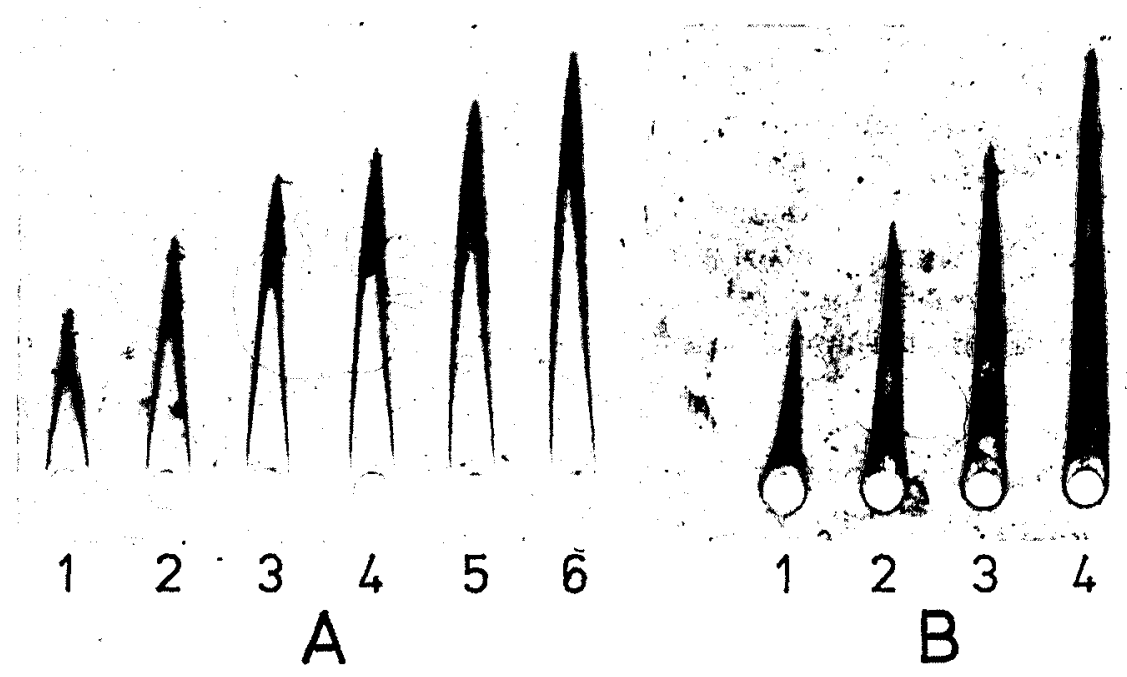

Fig. 2. Coomassie-blue stained immunoprecipitates (rockets) of a pooled human serum with anti- $A_{1}$ (A) and anti-B (B) goat serum. Conditions of the electroimmunoassay were : (A) $2.0 \%$ goat anti-human apo-A $A_{1}$ serum; antigen wells $1-6$ contained $15 \mu$ human serum diluted with $150 \mathrm{mM} \mathrm{NaCl}$ (1 plus 119,1 plus 74,1 plus 54,1 plus 42,1 plus 34 and 1 plus 29 respectively). Surface area/dilution, $r=0.999$. (B) $0.5 \%$ goat anti-human apo-B serum; antigen wells $1-4$ contained $15 \mu \mathrm{l}$ diluted human serum ( 1 plus 16 , 1 plus 8,1 plus 6 , and 1 plus 4 respectively). Surface area/dilution, $r=0.998$.

$\mathrm{B}$ determinations and for lipoprotein fractionation by the procedure of Redgrave et al. [23] with several modifications. To visualize the lipoprotein bands after ultracentrifugation, $3 \mathrm{ml}$ serum was mixed with $0.3 \mathrm{ml} 0.02 \%(\mathrm{w} / \mathrm{v}$ ) Sudan Black (Difco Laboratories) dissolved in dimethylsulphoxide. The background density of the mixture was raised to 1.210 with solid $\mathrm{KBr}(0.9552 \mathrm{~g})$. On top of the serum a discontinuous density gradient was built up in a centrifuge tube $(14 \times 89 \mathrm{~mm}, 13 \mathrm{ml})$ with salt solutions of $\mathrm{d}=1.063(4.5 \mathrm{ml})$ followed by $\mathrm{d}=$ $1.006(4.5 \mathrm{ml})$. These salt solutions contained EDTA $(0.1 \mathrm{mg} / \mathrm{ml})$ and were prepared from $\mathrm{NaCl}$ and $\mathrm{KBr}$ [24]. Centrifugation was carried out at $20^{\circ} \mathrm{C}$ and. $40000 \mathrm{rpm}\left(\mathrm{RCF}_{\max }=272,700 \times \mathrm{g}\right)$ for $16 \mathrm{~h}$ and the clearly visible bands of VLDL, LDL and HDL were harvested by tube slicing [25]. Lipoprotein cholesterol concentrations were determined according to Abell et al. [20]. Serum VLDL and LDL triglyceride concentrations were measured as described by Soloni [26].

Apoproteins were measured in whole serum by rocket immunoelectrophoresis [27] (see Fig. 2). Monospecific antisera against human apoprotein-B and apoprotein- $A_{1}$ were raised in goats using pure apo-B in $L D L ~(1.040<d<$ $1.053 \mathrm{mg} / \mathrm{ml}$ ) and pure apo- $\mathrm{A}_{1}[28,29]$ as antigens. Electrophoresis was performed at $\mathrm{pH} 8.6$ using $0.8 \%$ agarose (apo-B assay) or $0.8 \%$ agarose, $5 \%$ dextran $\mathrm{T} 10$ (apo- $\mathrm{A}_{1}$ assay) in $50 \mathrm{mM}$ diethylbarbiturate buffer as supporting medium for the antisera.

The electrophoresis was performed at $2.5 \mathrm{~V} / \mathrm{cm}$ for $16 \mathrm{~h}$ (apo-B) or at 3.5 $\mathrm{V} / \mathrm{cm}$ for $10 \mathrm{~h}$ (apo- $\mathrm{A}_{1}$ ). Serum samples were analysed in three dilutions. For one subject the samples obtained at the start and at the end of the test period were always analysed on one plate in order to minimise the effect of inter-assay variability. Because isolated LDL solutions become turbid during prolonged 
preservation, day to day calibration standards of a pooled serum were prepared in four dilutions. The apo-B and apo- $A_{1}$ contents in this secondary calibration standard were determined with freshly isolated pure LDL and pure apo- $\mathrm{A}_{1}$ and redetermined periodically. The protein content in the primary standards was determined by quantitative amino acid analysis. Analytical error was monitored by analysing a sample from a control pool on each plate. The combined withinday and between-day coefficients of variation for this control serum were $7 \%$ and $9 \%$ for the apo-B and the apo- $\mathrm{A}_{1}$ assays respectively.

\section{Statistical evaluation}

The individual values at the beginning and the end of the test period were compared per group, using a paired two-tailed $t$-test. Each subject thus served as his own control.

\section{Results}

The time courses of serum total cholesterol, serum total triglycerides and HDL cholesterol are presented in Figs. 3, 4 and 5 respectively.

All groups received the moderate fat, high PUFA MOD diet for the initial 2.5 week control period. By this time the mean serum total cholesterol concentration had decreased significantly by $0.46 \mathrm{mmol} / 1$ (Fig. 3), of which $0.06 \mathrm{mmol} / \mathrm{l}$ was located in HDL (Fig. 5). Serum total triglycerides had decreased by 0.12 $\mathrm{mmol} / \mathrm{l}$ (Fig. 4). Although the groups were matched for initial total serum cholesterol there were slight differences in initial values of HDL cholesterol and total serum triglycerides (Figs. 3 and 4). However, neither these initial values nor the changes in these parameters during the control period differed significantly between the groups. When the subjects changed from the MOD diet to the test diets, the concentrations of serum cholesterol remained unchanged in groups MOD and HIPUF and increased significantly in groups LO and HISAT, by 0.25 and $0.38 \mathrm{mmol} / \mathrm{l}$ respectively. HDL cholesterol concentration was unchanged in groups LO and MOD, but increased significantly in groups HIPUF and HISAT, by 0.10 and $0.12 \mathrm{mmol} / 1$ respectively. Total triglyceride concen-

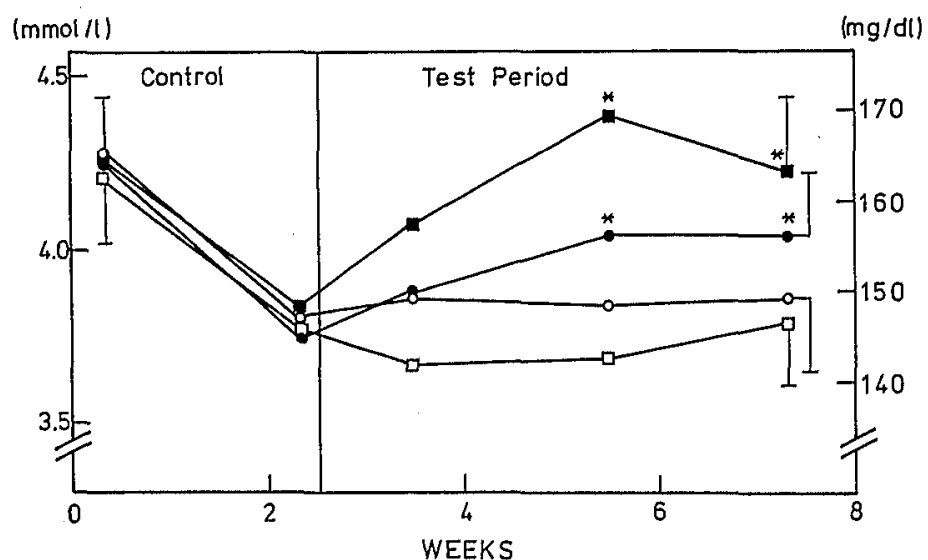

Fig. 3. Mean total serum cholesterol concentrations"during the experiment. $\longrightarrow \longrightarrow$, LO; $0 \longrightarrow$, MOD; $\square \longrightarrow \longrightarrow$, HIPUF; $-\longrightarrow$, HISAT. Vertical bars indicate 1 SEM; an asterisk denotes a significant difference $(P<0.05$ or 0.01$)$ from the value at the end of control period. 


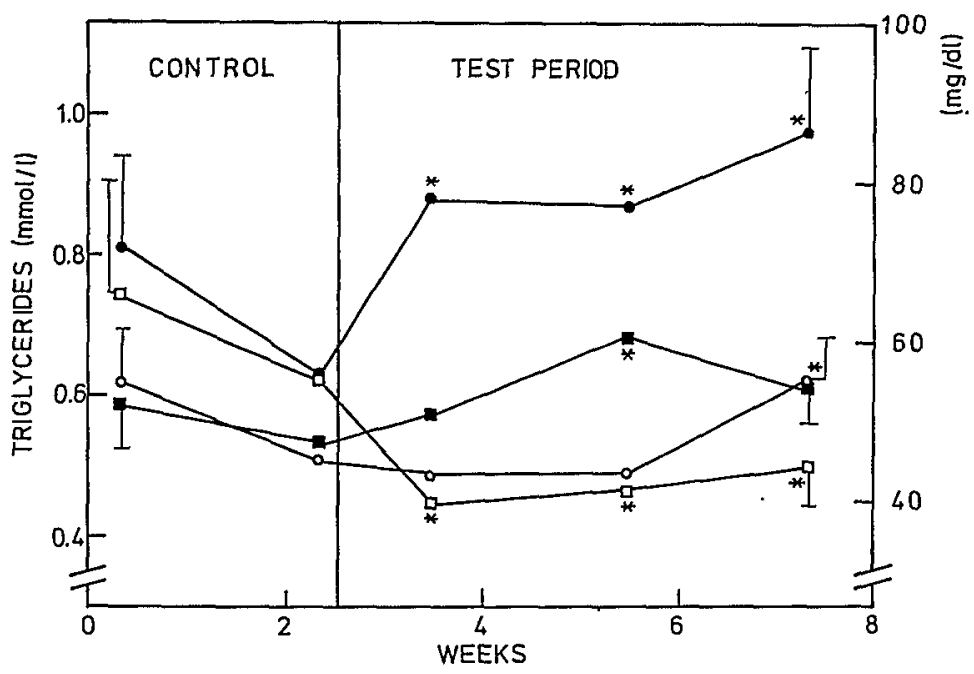

Fig. 4. Mean total serum triglycerides duxing the experiment. $\longrightarrow \longrightarrow$, LO; $\bigcirc \longrightarrow$, MOD; $\square \longrightarrow \square$, HIPUF; $\longrightarrow$, HISAT. Vertical bars indicate 1 SEM; an asterisk denotes a significant difference $(P<$ 0.05 or 0.01 ) from the value at the end of control period.

tration increased significantly in group LO by $0.35 \mathrm{mmol} / \mathrm{l}$ and in group MOD by $0.11 \mathrm{mmol} / \mathrm{l}$.

Data for lipoprotein lipids and serum apolipoproteins are presented in Tables 2,3 and 4 respectively. In all groups HDL cholesterol and serum apo- $\mathrm{A}_{1}$ concentrations were slightly but not significantly higher for females than for males.

As HDL cholesterol was unchanged in group LO the rise in total serum cholesterol in this group was entirely located in the LDL and VLDL fractions $(0.38$ and $0.09 \mathrm{mmol} / 1$ respectively). This was accompanied by an increase of $118 \pm$ $60 \mathrm{mg} / \mathrm{l}$ in serum apo-B concentration, but the LDL/apo-B ratio remained the same (Table 4). Although HDL cholesterol remained constant, HDL composition changed as judged by the HDL cholesterol/apo- $A_{1}$ ratio, which decreased significantly (Table 4). VLDL triglycerides increased significantly by 0.14 $\mathrm{mmol} / \mathrm{l}$ and LDL triglycerides by $0.08 \mathrm{mmol} / \mathrm{l}$ (Table 2 ).

The MOD group, which continued on the control diet during the test period,

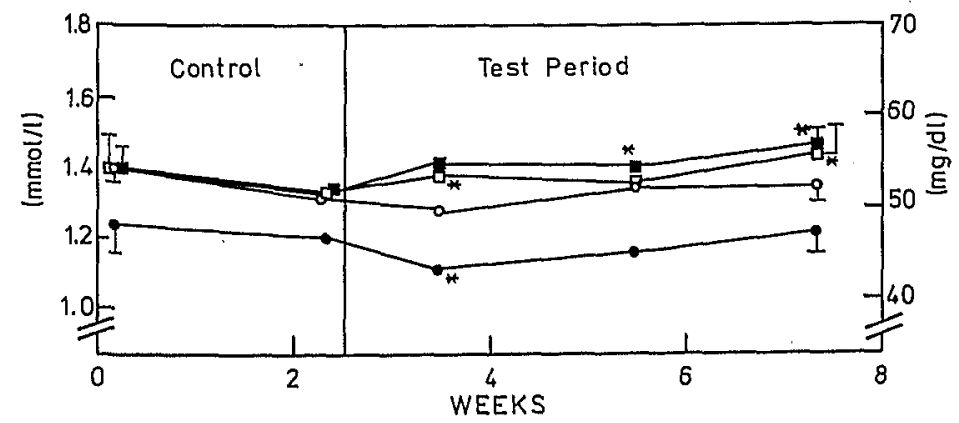

Fig. 5. Mean serum HDL cholesterol during the experiment, $\longrightarrow \longrightarrow$, LO; $\bigcirc-0$, MOD; $\square \longrightarrow \square$, HIPUF; $\longrightarrow$, HISAT. Vertical bars indicate 1 SEM; an asterisk denotes a significant difference $(P<$ 0.01 or 0.05 ) from the value at the end of control period. 


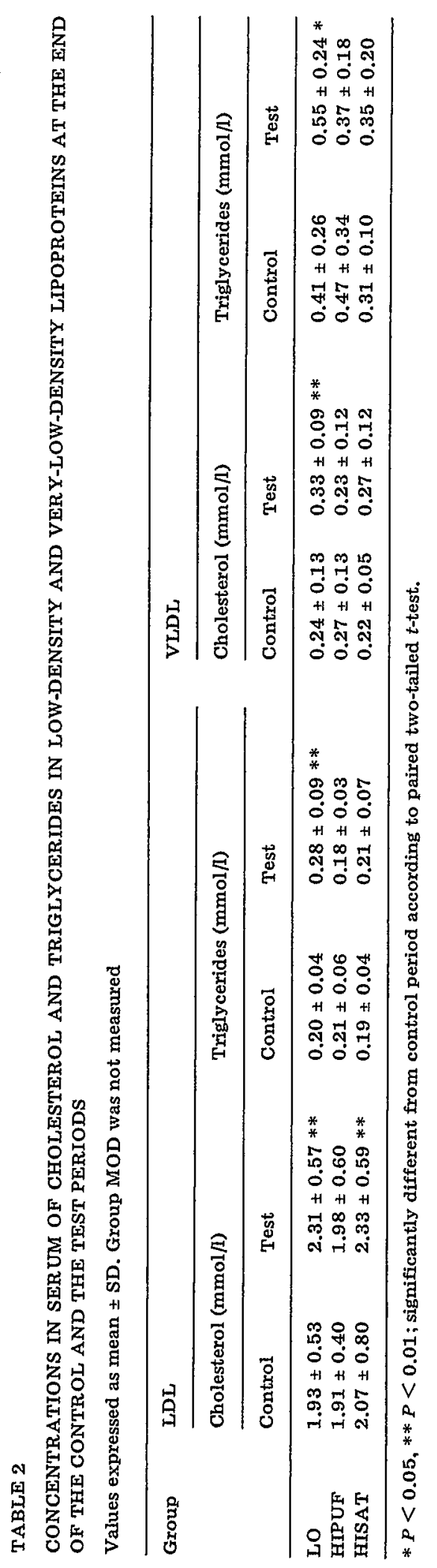


TABLE 3

CONCENTRATIONS IN SERUM OF APOLIPOPROTEIN-A 1 AND APOLIPOPROTEIN-B AT THE END OF THE CONTROL AND THE TEST PERIODS

Values expressed as mean \pm SD

\begin{tabular}{llllll}
\hline Group & apo-A $1(\mathrm{mg} / \mathrm{l})$ & & & apo-B $(\mathrm{mg} / \mathrm{l})$ & \\
\cline { 2 - 3 } & Control & Test & & Control & Test \\
\hline LO & $1068 \pm 151$ & $1138 \pm 149 * *$ & & $627 \pm 163$ & $\mathbf{7 3 2} \pm 165 * *$ \\
MOD & $1089 \pm 150$ & $1201 \pm 149 * *$ & & $544 \pm 143$ & $541 \pm 122$ \\
HIPUF & $1271 \pm 127$ & $1295 \pm 109$ & & $580 \pm 103$ & $574 \pm 120$ \\
HISAT & $1178 \pm 205$ & $1278 \pm 162 * *$ & & $664 \pm 202$ & $718 \pm 175 * *$ \\
\hline
\end{tabular}

$* * P<0.01$; significantly different from control period according to paired two-tailed $t$-test.

The correlation coefficient between LDL cholesterol and serum apo-B was $r=0.87(n=60)$; the correlation coefficient between HDL cholesterol and sexum apo-A $A_{1}$ was $r=0.58$. Rather low correlation coefficients between serum apo- $A_{1}$ and HDL cholesterol in normolipemics have also been published by other authors $[28,45-47]$.

showed very little change. Although serum total and HDL cholesterol concentration remained unchanged, the HDL cholesterol/apo- $\mathrm{A}_{1}$ ratio decreased significantly. Total triglycerides increased by $0.11 \mathrm{mmol} / 1$, after an initial decrease of $0.11 \mathrm{mmol} / \mathrm{l}$ in the control period (Fig. 4).

Surprisingly, the effects of the HIPUF diet, in which an additional 10 energy $\%$ of carbohydrates had been replaced by PUFA, did not differ greatly from the MOD diet. Total serum cholesterol remained reasonably constant compared with during the control period, but HDL cholesterol increased significantly by $0.10 \mathrm{mmol} / \mathrm{l}$ (Fig. 5). There was a minor increase in the HDL cholesterol/ apo- $\mathrm{A}_{1}$ ratio (Table 4 ). Total triglycerides decreased significantly by 0.13 $\mathrm{mmol} / \mathrm{l}$ (Fig. 4); this decrease mainly took place in VLDL $(0.09 \mathrm{mmol} / \mathrm{l})$.

The high-fat low-PUFA diet caused a significant increase in serum cholesterol concentration. It is noteworthy, however, that of the total increase of 0.38 $\mathrm{mmol} / \mathrm{l}$, about $30 \%$ was accounted for by HDL. Total serum triglycerides

\section{TABLE 4}

CHOLESTEROL/APOLIPOPROTEIN RATIOS AT THE END OF THE CONTROL AND THE DIETARY TEST PERIODS

Apoprotein values are for whole serum. HDL cholesterol was determined after manganese-heparin precipitation and LDL cholesterol after density gradient centrifugation. Values expressed as mean $\pm S D$.

\begin{tabular}{llllll}
\hline Group & \multicolumn{2}{l}{ HDL cholesterol/apo- $\mathrm{A}_{1}(\mathrm{mmol} / \mathrm{g})$} & & \multicolumn{2}{l}{ LDL cholesterol/apo-B (mmol/g) } \\
\cline { 2 - 3 } & Control & Test & & Control & Test \\
\hline LO & $1.13 \pm 0.19$ & $1.07 \pm 0.18 *$ & & $3.2 \pm 0.5$ & $3.2 \pm 0.5$ \\
MOD & $1.22 \pm 0.18$ & $1.13 \pm 0.15 *$ & & $-\mathrm{a}$ & $-\mathrm{a}$ \\
HIPUF & $1.05 \pm 0.17$ & $1.11 \pm 0.14 *$ & & $3.3 \pm 0.3$ & $3.4 \pm 0.4$ \\
HISAT & $1.14 \pm 0.12$ & $1.15 \pm 0.11$ & & $3.1 \pm 0.6$ & $3.2 \pm 0.3$ \\
\hline
\end{tabular}

a Not measured.

$* P<0.05$; significantly different from control period according to paired two-tailed $t$-test. 
increased by $0.07 \mathrm{mmol} / \mathrm{l}$, and serum apo-B concentration by $54 \mathrm{mg} / \mathrm{l}$ (Table 3).

In all groups, the LDL cholesterol/apo-B ratio remained constant as compared with the control period (Table 4).

\section{Discussion}

Participants in this study were well-motivated, normolipidemic students of the Agricultural University. We have repeatedly found $[17,30]$ that the fat and cholesterol consumption in this population is lower than the average intake in this country (Table 1 ). Thus the change from 'habitual' diet to the rigidly controlled MOD diet in the control period of our study mainly involved an increase in the $\mathrm{P} / \mathrm{S}$ ratio (Table 1). The observed decrease in serum cholesterol and triglycerides is in agreement with earlier studies [31], although the fall in total cholesterol is somewhat larger than expected [31]. This could be due to adaptation to laboratory conditions and to an inaccurate estimation of their habitual fat intake.

At this level of fat intake (30\% of energy), our data showed a decrease in HDL cholesterol on the high $\mathrm{P} / \mathrm{S}$ diet, a result previously described by Shepherd et al. [32] in dietary studies in normo- and hyperlipidemic men. However, as discussed below, we were unable to demonstrate such a change under controlled conditions at a higher fat intake level ( $40 \%$ of energy).

The effects of a change from MOD to LO, HIPUF and HISAT diets on serum lipoproteins were studied under rigidly controlled conditions as was the effect of prolonged consumption of the MOD diet. In the latter (MOD) group no changes in serum total cholesterol, HDL cholesterol and serum apo-B concentrations were observed between 3 and 8 weeks, indicating that these parameters were stabilised already by the end of the control period. However, this was not the case for HDL composition as serum apo- $\mathrm{A}_{1}$ concentrations rose significantly during the test period.

Changing from the MOD to the LO diet involved a replacement of 8 energy $\%$ PUFA by carbohydrates. VLDL increased significantly by this treatment, probably by carbohydrate-induced synthesis [33,34] which may have been reinforced by the decrease in PUFA.

A pertinent finding was the increase in LDL, reflected by the simultaneous rise in LDL cholesterol and serum apo-B concentrations $(+17 \%)$. Whether the rise in LDL is mediated by an increased conversion of VLDL into LDL [3638] or by a delayed LDL degradation [39] (the phospholipid moiety of LDL may be more saturated on this carbohydrate-rich diet [35]) is at present not known.

One might speculate that the decreased HDL cholesterol/apo- $A_{1}$ ratio in the $\mathrm{LO}$ group reflected a shift from the cholesterol-rich $\mathrm{HDL}_{2}$ fraction to the $\mathrm{HDL}_{3}$ fraction [42].

Changing from the MOD to the HIPUF diet implied that 8 energy $\%$ of carbohydrates were replaced by PUFA. The further increase in dietary linoleic acid did not cause significant changes in LDL and VLDL cholesterol values or serum apo-B. Although this indicates that the HIPUF diet was no more effective in depressing serum LDL levels than the MOD diet, total serum 
triglycerides decreased on the HIPUF diet and a significant rise in HDL cholesterol was observed, which was not accompanied by an increase in serum apo- $\mathrm{A}_{1}$ concentration.

On changing from the MOD to the HISAT diet, 8 energy \% PUFA plus 8 energy $\%$ carbohydrates were both replaced by saturated fat resulting in a significant increase in serum LDL concentrations judged from the proportional change in LDL cholesterol and serum Apo-B concentrations. HDL cholesterol as well as serum apo- $A_{1}$ concentrations were also significantly increased. At this level of fat intake (40 energy \%), no differences in HDL cholesterol and apo- $\mathrm{A}_{1}$ concentrations between the HISAT and the HIPUF diet were present. Lower VLDL and LDL levels on PUFA-rich diets such as MOD and HIPUF, compared with saturated fat-rich diets, such as HISAT, have been reported repeatedly. VLDL synthesis and conversion into LDL may be decreased on high P/S diets [36-38] although a recent report points to increased LDL catabolism [39].

Although different amounts and types of fat in the diet will also affect postprandial chylomicron production [40], it is unlikely that this will lead directly to changes in serum LDL concentrations. Small quantities of LDL can indeed be formed by chylomicron degradation but it can be calculated that the contribution of this pathway to the overall LDL synthesis is very limited.

Potential effects of diet on serum HDL are important since serum HDL cholesterol concentrations have been inversely correlated with risk of cardiovascular disease [2-4]. Recently the effect of a diet rather similar to our MOD diet on serum HDL cholesterol concentrations in hyperlipidemic subjects has been studied by Hjermann et al. [41] and compared with a HISAT type diet. In this intervention study a $20 \%$ increase in HDL cholesterol on the MOD-type diet was observed after 4 years. However, it cannot be excluded that this rise was due to the decreases in serum triglyceride concentrations, obesity and cigarette smoking rather than to the diet.

In addition to changes in HDL cholesterol, the average composition of HDL in our experiment was obviously sensitive to diet, although the changes were small.

In order to illuminate the effects of the different diets, we calculated the ratio of the concentration of HDL cholesterol to total cholesterol and of apo- $A_{1}$ to apo-B (Table 5). If LDL is "atherogenic" and HDL is "anti-athero-

TABLE 5

HDL/TOTAL CHOLESTEROL AND APO-A 1 /APO-B RATIOS AT THE END OF THE CONTROL AND TEST PERIODS

\begin{tabular}{|c|c|c|c|c|}
\hline \multirow[t]{2}{*}{ Group } & \multicolumn{2}{|c|}{ HDL/total cholesterol } & \multicolumn{2}{|c|}{ Apo-A $A_{1} /$ Apo-B } \\
\hline & Control & Test & Control & Test \\
\hline Lo & $0.33 \pm 0.07$ & $0.31 \pm 0.08 * *$ & $1.82 \pm 0.55$ & $1.67 \pm 0.61 * *$ \\
\hline MOD & $0.35 \pm 0.07$ & $0.36 \pm 0.05$ & $2.14 \pm 0.65$ & $2.29 \pm 0.41$ \\
\hline HIPUF & $0.35 \pm 0.06$ & $0.38 \pm 0.06 * *$ & $2.24 \pm 0.38$ & $2.32 \pm 0.37$ \\
\hline HISAT & $0.36 \pm 0.06$ & $0.35 \pm 0.05$ & $1.93 \pm 0.64$ & $1.86 \pm 0.42$ \\
\hline
\end{tabular}

$* * P<0.01$; significantly different from control period according to paired two-tailed $t$-test. 
genic" then these ratios may have predictive value for atherogenic risks. On the HISAT diet the ratios showed surprisingly little change compared with the MOD diet. The low level of dietary cholesterol may have contributed to this result; there are indications [43] that satured fat and dietary cholesterol reinforce each other's effect on serum (LDL) cholesterol levels; the effects of a high saturated fat intake might have been more pronounced if the experiment had been performed at a higher level of cholesterol consumption. The HIPUF diet showed a trend towards more favourable ratios in contrast to the LO diet where unfavourable changes were observed. However, the latter could in part be due to the relatively short test period of 5 weeks. It is known that after 2-3 months on high carbohydrate diets serum triglyceride concentration will go down again [44]. It is not known if similar long-term changes in HDL cholesterol and apolipoproteins could appear; this should be investigated in long-term dietary studies.

\section{References}

1 Blackburn, H., Chapman, J., Dawber, T.R., Doyle, J.T., Epstein, F.H., Kannel, W.B., Keys, A., Moore, F., Paul, O., Stamler, J. and Taylor, H.L., Revised data for 1970 ICHD report, Amer. Heart J., 94 (1977) 539.

2 Gofman, J.W., Hanig, M., Jones, H.B., Lauffer, M.A., Lawry, E.Y., Lewis, L.A., Mann, G.V., Moore, F.E., Olmsted, F., Yeager, J.F., Andrus, E.C., Barach, J.H., Beams, J.W., Fertig, J.W., Page, I.H., Shannon, J.A., Stare, F.J. and White, P.D., Evaluation of serum lipoprotein and cholesterol measurements as predictors of clinical complications of atherosclexosis, Circulation, 14 (1956) 691.

3 Gordon, T., Castelli, W.P., Hjortland, M.C., Kannel, W.B. and Dawbex, T.R., High density lipoprotein as a protective factor against coronary heart disease - The Framingham Study, Amer. J. Med., 62 (1977) 707.

4 Miller, N.E., F $\phi$ rde, O.H., Thelle, D.S. and Mjфs, O.D., The Troms $\phi$ heart-study. High-density lipoprotein and coronary heart-disease - A prospective case-control study, Lancet, i (1977) 965.

5 Barr, D.P., Russ, E.M. and Eder, H.A., Protein-lipid relationships in human plasma, Amer. J. Med., 11 (1951) 480 .

6 Miller, G.J. and Millex, N.E., Plasma-high-density lipoprotein concentration and development of ischaemic heart-disease, Lancet, $\mathrm{i}$ (1975) 16.

7 Nikkilä, E., Studies on the lipid-protein relationships in normal and pathological sera and the effect of heparin on serum lipoproteins, Scand. J. Clin. Lab. Invest., 5 Suppl. 8 (1953) 1.

8 Albers, J.J., Cheung, M.C. and Hazzard, W.R., High-density lipoproteins in myocardial infarction survivors, Metabolism, 27 (1978) 479

9 Curxy, M.D., Alaupovic, P. and Suenran, C.A., Determination of apolipoprotein A and its constitutive $A_{I}$ and $A_{I I}$ polypeptides by separate electro-immunoassays, Clin. Chem., 22 (1976) 315

10 Durrington, P.N., Bolton, C.H. and Hartog, M., Serum and lipoprotein apolipoprotein B levels in normal subjects and patients with hypexlipoproteinaemia, Clin. Chim. Acta, 82 (1978) 151.

11 Avogaro, P., Bittolo Bon, G., Cazzolato, G, and Quinci, G.B., Are lipoproteins better discriminators than lipids for atherosclerosis?, Lancet, $\mathrm{i}$ (1979) 901.

12 Burslem, J., Schonfeld, G., Howald, M.A., Weidman, S.W. and Millex, J.P., Plasma apoprotein and lipo* protein lipid levels in vegetarians, Metabolism, 27 (1978) 711.

13 Dayton, S., Pearce, M.L., Hashimoto, S., Dixon, W.J. and Tomiyasu, U., A Controlled Clinical Trial of a Diet High in Unsaturated Fat, American Heart Association Monograph, No. 25, New York, 1969

14 Miettinen, M., Tuxpeinen, O., Karvonen, M.J., Elosuo, R. and Paavilainen, E., Effect of cholesterollowering diet on mortality from coronary heart-disease and othex causes - A twelve-year clinical trial in men and women, Lancet, 2 (1972) 835.

15 Page, L. and Marston, R.M., Food consumption patterns - U.S. diet. In: R.J. Havlik and M. Feinleib (Eds.), Proceedings of the Conference on the Decline in Coxonary Heart Disease Mortality, NIH Publication 79-1610, 1979, pp. 236-243.

16 Hautvast, J.G.A.J., Ontwikkeling van een systeem om gegevens van voedingsenquetes met behulp van de computer te verwerken, Voeding, 36 (1975) 356.

17 Stasse-Wolthuis, M., Albers, H.F.F., Jeveren, J.G.C. van, Jong, J.W. de, Hautvast, J.G.A.J., Hermus R.J.J., Katan, M.B., Brydon, W.G. and Eastwood, M.A., Influence of dietary fiber from vegetables and fruits, bran or citrus pectin on serum lipids, fecal lipids and colonic function, Amer. J. Clin. Nutx., 33 (1980) In press. 
18 Cummings, J.H., Jenkins, D.J.A. and Wiggins, H.S., Measurement of the mean transit time of dietary residue through the human gut, Gut, 17 (1976) 210.

19 Huang, T.C., Chen, C.P., Wefler, V. and Raftery, A., A stable reagent for the Liebermann-Burchard reaction - Application to rapid serum-cholestexol determination, Anal. Chem., 33 (1961) 1405.

20 Abell, L.L., Levy, B.B., Brody, B.B. and Kendall, F.E., A simplified method for the estimation of total cholesterol in serum and a demonstration of its specificity, J. Biol. Chem., 195 (1952) 357.

21 Burstein, M. and Samaille, J., Sur un dosage rapide du cholesterol lié au $\alpha$ - et $\beta$-lipoproteins du serum, Clin. Chim. Acta, 5 (1960) 609.

22 Haar, F. Van der, Gent, C.M. Van, Schouten, F.M. and Voort, H.A. Van der, Methods for the estimation of high density cholesterol, comparison between two laboratories, Clin. Chim. Acta, 88 (1978) 469 .

23 Redgrave, T.G., Roberts, D.C.K. and West, C.E., Separation of plasma lipoproteins by density gradient ultracentrifugation, Anal. Biochem., 65 (1975) 42.

24 Havel, R.J., Eder, H.A. and Bragdon, J.H., The distribution and chemical composition of ultracentrifugally separated lipoproteins in human serum, J. Clin. Invest., 34 (1955) 1345.

25 Manual of Laboratory Operations, Lipid Research Clinics Program, Vol. 1 (Lipid and Lipoprotein Analysis) (DHEW Publ, (NIH)75-628), U.S. Govt. Printing Office, Washington, 1974.

26 Soloni, F.G., Simplified manual micromethod for determination of serum triglycerides, Clin. Chem., 17 (1971) 529 .

27 Laurell, C.B., Electroimmunoassay, Scand. J. Clin, Lab. Invest., Suppl. 124 (1972) 21.

28 Schonfeld, G. and Pfleger, B., The structure of human high density lipoprotein and the levels of apolipoprotein $A_{1}$ in plasma as determined by radioimmunoassay, J. Clin. Invest., 54 (1974) 236.

29 Lux, S.E, and John, R.M., Furthex characterization of the polymorphic forms of a human high density apolipoprotein, A poLP-Glu-1 (apo A1), Biochim. Biophys. Acta, 278 (1972) 266.

30 Stasse-Wolthuis, M., Hautvast, J.G.A.J., Hermus, R.J.J. Katan, M.B., Bausch, J.E., Rietberg-Brussaard, J.H., Velema, J.P., Zondervan, J.H., Eastwood, M.A. and Brydon, W.G., The effect of a natural highfiber diet on serum lipids, fecal lipids and colonic function, Amer. J. Clin. Nutr., 32 (1979) 1881.

31 Keys, A., Anderson, J.T. and Grande, F., Serum cholesterol response to changes in the diet, Metabolism, 14 (1965) 747.

32 Shepherd, J., Packard, C.J., Patsch, J.R., Gotto, Jr., A.M. and Taunton, O.D., Effects of dietary polyunsaturated and saturated fat on the properties of high density lipoproteins and the metabolism of apolipoprotein $A_{1}$, J. Clin. Invest., 61 (1978) 1582.

33 Schonfeld, G., Weidman, S.W., Witztum, J.L. and Bowen, R.M., Alterations in levels and interrelations of plasma apolipoprotein induced by diet, Metabolism, 25 (1976) 261.

34 Wilson, D.E. and Lees, R.S., Metabolic relationships among the plasma lipoproteins. Reciprocal changes in the concentrations of very low and low density lipoproteins in man, J. Clin. Invest., 51 (1972) 1051 .

35 Thompson, G.R., Jadhav, A., Nava, M. and Gotto, A.M., Effect of intravenous phospholipid on low density lipoprotein turnover in man, Europ. J. Clin. Invest., 6 (1976) 241.

36 Yeshurun, D., Gotto, Jr., A.M. and Taunton O.D., Effect of polyunsaturated versus saturated fat on LDL metabolism in normal subjects, Clin. Res., 24 (1976) 373 Abstract.

37 Shepherd, J., Packard, C.J., Gotto, Jr., A.M. and Taunton, O.D., Effects of dietary saturated and polyunsaturated fat on the metabolism of apolipoproteins $A_{1}$ and $B$. - Study of a patient with type II-b hyperlipoproteinaemia, Clin. Chim. Acta, 87 (1978) 395.

38 Shepherd, J., Packard, C., Morgan, G., Taunton, D. and Gotto, Jr., A., The influence of dietary-fat saturation on the metabolism of apolipoproteins $A_{1}, B$ and $C$ in a type II-b hyperlipoproteinaemic subject, Biochem. Soc. Trans., 6 (1978) 592.

39 Shepherd, J., Packard, J., Grundy, S.M., Yeshurun, D., Gotto, A.M. and Taunton, O.D., Effects of saturated and polyunsaturated fat diets on the chemical composition and metabolism of low density lipoprotein in man, J. Lip. Res., 21 (1980) 91.

40 Ocknex, R.K. and Jones, A.L., An electron microscopic and functional study of very low density lipoproteins in intestinal lymph, J. Lipid Res., 11 (1970) 284.

41 Hjermann, I., Enger, S.C., Helgeland, A., Holme, I., Leren, P. and Trygg, K., The effect of dietary changes on high density lipoprotein cholesterol - The Oslo Study, Amex. J. Med., 66 (1979) 105.

42 Blum, C.B., Levy, R.I., Eisenberg, S., Hall, M., Goebel, B.H. and Berman, M., High density lipoprotein metabolism in man, J. Clin. Invest., 60 (1977) 795.

43 Bronsgeest-Schoute, D.C., Hermus, R.J.J. and Hautvast, J.G.A.J., Dependence of the effects of dietary cholesterol and experimental conditions on serum lipids in man, Part I (Effects of dietary cholesterol in a linoleic-acid-rich diet), Amer. J. Clin. Nutr., 32 (1979) 2183.

44 Antonis, A. and Bersohn, I., The influence of diet on serum triglycerides in South African White and Bantu prisoners, Lancet, i (1961) 3.

45 Karlin, J.B., Juhn, D.J., Slarr, J.I., Scanu, A.M. and Rubenstein, A.H., Measurement of human high density lipoprotein apolipoprotein $A_{1}$ in serum by radioimmunoassay, J. Lipid Res., 17 (1976) 30.

46 Cheung, M.C. and Albers, J.J., The measurement of apolipoprotein $A_{1}$ and $A_{I I}$ levels in men and women by immunoassay, J. Clin. Invest., 60 (1977) 43.

47 Herbert, P.N. and Henderson, L.O., Plasma-trigly cerides do not regulate high-density lipoprotein concentrations, Lancet, 1 (1979) 1368. 